\title{
DYNAMICS OF THE EDUCATIONAL PROCESS IN RUSSIAN UNIVERSITIES
}

\author{
Cherenkov, Roman Alexandrovich ${ }^{1}$, Baryshnikov, Sergey Viktorovich ${ }^{2}$ \\ ${ }^{1}$ Candidate of Historical Sciences, Associate Professor of the Department of Philosophy and \\ History, Voronezh State University of Engineering Technologies, Revolution Avenue, 19, \\ Voronezh, Russia, E-mail: marselles2006@mail.ru \\ ${ }^{2}$ Candidate of Philosophical Sciences, Associate Professor of the Department of Philosophy and \\ History, Voronezh State University of Engineering Technologies, Revolution Avenue, 19, \\ Voronezh, Russia, E-mail: ser-baryshnikov@yandex.ru
}

\begin{abstract}
It is known that fundamental higher education is one of the foundations of successful socio-economic and socio-political development of modern states. An important component of the process of integration of the Russian Federation into the world community, which has been taking place in recent years, is the construction of effective interaction between the domestic and European educational systems, which causes legitimate interest among researchers and requires a deep and comprehensive study of a whole range of problems. Both the problem and its actual side, despite the existing work, are far from being exhausted.
\end{abstract}

Keywords: education, institute, society, state, city.

\section{INTRODUCTION}

The relevance of the article is determined by the fact that in recent years Russian historical science is experiencing a qualitatively new stage in its development, associated, first of all, with the conceptual rethinking of many aspects of national history of the second half of the 90s of the XX century, the beginning of the XXI century, in which the history of formation and implementation integration educational processes in the Russian Federation and European states in terms of comparative analysis, their experience, problems and prospects occupies one of the important places.

In the new political, legal and economic situation, the question of creating an effective system for training highly qualified personnel in the Russian Federation has become acute. Its solution is impossible without taking into account the world, and, in particular, European experience, which makes the topic of the article modern and practically in demand. The Russian Federation joined the process of forming a common European area of higher education in 2003 at a stage when European countries accumulated fifty years of experience of cooperation in this area. In this regard, the relevance of the problem, its scientific and practical significance is an analysis of the main directions, stages, forms, methods, approaches to integration cooperation in the historical period under study.

\section{METHODOLOGY}

The methodological basis of the article is the principles of historical science: historicism, objectivity, comprehensiveness of study, reliability, which make it possible to see historical processes in their real development and interconnection, to conduct a comprehensive analysis and assessment of facts. The 
principle of historicism is the traditional principle of historical research, which requires a specific study of social phenomena in their development and change, a comprehensive study of the connection and interrelation of each of these elements with others. The principle of objectivity makes it possible to understand the basic values, as well as to consider and analyze the positive and negative phenomena of the historical process in the modernization of Russian and European higher education.

\section{RESULTS}

The historical prerequisites for the internationalization and globalization of higher professional education were determined in the 1990s. and the initial period of the XXI century, not only by external geopolitical factors, but also by national socio-economic and historical contexts, necessary opportunities, resources and priorities. Thus, the internationalization of higher education in an increasing number of countries, including the Russian Federation, is becoming the object and subject of a purposeful policy on the part of the state aimed at solving specific domestic political, social and financial problems. An analysis of the approaches, mechanisms and experience of both the Russian Federation and European states that are most successfully implementing the policy of internationalization can certainly be useful in the further development of tools for implementing the strategy of internationalization of higher professional education both in European countries and in the Russian Federation.

Globalization in higher professional education and the transition to a knowledge society place new and significant demands on universities as centers of knowledge. Research in this area is a critical activity. It is known that the educational process has long been international in nature, its internationalization is significantly accelerating. International relations in the field of education and university science, due to the availability of communications in the form of publications, conferences, the use of information and communication technologies and networks within the university community, as well as the quality of teaching and research personnel, assessed in accordance with international standards, should, as shown in article, first of all, to be developed by universities. These tendencies are increasingly manifested in such large Russian universities as Moscow State University. Lomonosov, Peoples' Friendship University of Russia, St. Petersburg State University, etc.

The effect of the globalization of the educational process is that the academic profession itself is becoming more mobile and extremely competitive in the international market for faculty and researchers. The result is the organized migration of scientists and, as a consequence, the "brain drain". The new role of universities as "centers of knowledge" and progressive teaching methods extends not only to science and pedagogy, but also to other functions. Universities are called upon to take more responsibility for the development of society and culture in general, to participate as mediators in conflicts, deepen democracy, and function as centers of critical discussion and moral conscience. The high degree of universally recognized requirements for universities creates a certain tension in them and encourages them to be more professional and better managed.

Since the mid-1990s. and especially at the beginning of the XXI century. the systems of higher professional education of the Russian Federation and the countries of the European Union have become the field of the most active formation and implementation of integration educational processes, the introduction of new approaches and priorities in higher professional education in accordance with the needs of the economy and society of a particular state. Many innovations in this area are associated with the modernization of continuous multi-level professional education and the development of national educational systems in Russia and European countries, with the process of diversification of higher professional education, etc. These and other innovations in higher education in the Russian Federation and the EU countries are largely the same and are a consequence of the modernization of its legal framework and a significant update of educational concepts, the result of joint activities of the Russian and European university community, the initiative of leaders, specialists and teaching staff.

The authors believe that the most important tasks of modernizing the system of higher professional education in Russia are its restoration and recovery on the basis of the latest achievements of European higher education, that is, the withdrawal of Russian higher professional education from the crisis of the 1990s. to the level of advanced European states; rational combination of Russian and European higher education; its reforming with the transition to horizontal structures of educational process management, taking into account the best practices of European universities; an increase in the quality of education and the level of training of highly qualified specialists based on modern European technologies, etc.

Analysis of new approaches and priorities of the Russian Federation and European states in the educational policy of the period under study allows us to conclude that it is possible to extend the existing innovative 
experience to the entire world system of higher professional education, taking into account the characteristics of each individual country.

\section{CONCLUSION}

For the successful integration of Russian higher education into the European system of higher education, it is necessary, according to the authors, firstly, to bring the list of training directions and specialties of higher professional education into line with the European one; secondly, to achieve the alignment of qualification requirements for specialists with higher professional education in the industry with the qualification characteristics contained in the state educational standards of higher professional education for the preparation of bachelors, graduates and masters; third, to improve the methodology of modular construction of educational programs of higher professional education; fourth, introduce a generally accepted credit system similar to ECT8; fifthly, to achieve the conformity of the system of final documents with the allEuropean one; sixth, to make the procedure for certification of educational programs effective as the most important aspect of the education quality assurance system; seventh, to increase academic mobility.

\section{REFERENCE LIST}

Ashmarov I.A., Volkova E.A., Frolova E.V. (2015). To the Question of Formation of Trends in the Higher Education System within the Framework of Modern Globalization Processes. Modern problems of science and education. №. 1-1. P. 975. (In Russ.)

Baidenko V. I. (2004) Competencies in professional education. Higher education in Russia. № 11. (in Russ).

Chistokhvapov V. N. (2009) The history of the development of academic mobility in the countries of the "Bolon zone". Pedagogical education and science. №. 9. Pp. 33-34. (in Russ).

Ershov B.A. (2010) The Russian Orthodox Church and secular power in the Voronezh province in the XIX early XX centuries. GOU VPO "Voronezh State Technical University". Voronezh. 167 p. (in Russ).

Ershov B.A. (2010) The system of spiritual education in Voronezh province in the 19th century. Education and Society. №. 5 (64). Pp. 105-108. (in Russ).

Ershov B.A., Ashmarov I.A. (2018) Interaction Of The Orthodox Church And The State In Russia At The Present Stage. Bulletin Social-Economic and Humanitarian Research. № 2. Pp. 19-24. (In Eng.)

Ershov B.A., Ashmarov I.A., Danilchenko S.L. (2018) The Development Of Russian Church Architecture In The 1990s-2017: The State And Prospects. Open archive article in № 1. 06.05.2018. (In Eng.)

Ershov B.A., Ashmarov I.A., Drobyshev A.V., Zhdanova T.A., Buravlev I.A. (2017) Property And Land Relations Of Russian Orthodox Church And State In Russia. The European Proceedings of Social \& Behavioural Sciences. Pp. 324-331. (In Eng.)

Ershov B.A., Fursov V.N. (2018) The Russian Church in the State Mechanism of Russia. Bulletin SocialEconomic and Humanitarian Research. № 1. Pp. 32-37. (in Engl).

Ershov B.A., Perevozchikova L.S., Romanova E.V. (2019) Globalization and Intensification of Spiritual Values in Russia in the Philosophical Aspect. 6th International Conference on Education and Social Sciences Abstracts \& Proceedings. Pp. 208-212. (in Engl).

Ershov B.A., Perevozchikova L.S., Romanova E.V., Ashmarov I.A. (2019) The Concept of Spirituality in Social Philosophy. Smart Innovation, Systems and Technologies. T. 139. Pp. 688-694. (in Engl).

Filippov V. M. (2001) Higher School of Russia facing the challenges of the XXI century. Higher education in Russia. №. 1. (in Russ).

Filippov V. M., Chistokhvalov V. N. (2003) Russian higher education: on the path of change. Bulletin of the RUDN. Series "History of Russia". №. 2. Pp. 7-20. (in Russ).

Kolesov V. P. (2002) Bachelor + master or only a specialist: 12 theses in favor of a multi-level system of higher education. Higher education today. №. 5. (in Russ).

Larionova M. V. (2005) The formation of a pan-European educational space. Tasks for the Russian higher school. Questions of education. №. 4. (in Russ). 
Pokholkov Yu. P., Chuchalip A. I., Boev O. V. (2005) Quality assurance of engineers ' training: accreditation of educational programs and certification of specialists. Questions of education. №. 4. (in Russ).

Rogers, P. J. (2008) Using Programme Theory to Evaluate Complicated and Complex Aspects of Interventions. Evaluation, 14 (1). (in Engl).

Romanova E.V., Perevozchikova L.S., Ershov B.A. (2017) The Lifestyle of the Human Being in the Information Society. 3rd International Conference on Advances in Education and Social Sciences Proceedings of ADVED Pp. 950-954. (in Engl).

Tatur Yu. G. (1999) The educational system of Russia: High school. (in Russ).

The Bologna Process Harmonizing Europe's Higher Education. (2006) Reinalda, Bob; Ku-lesza, Ewa. 2nd ed. Barbara Budrich Publishers. (in Russ).

The system of higher education in Japan. (2004) OECD News: Education, Science, New Economy. №. 7. (in Russ).

Tkach G. F., Chistokhvapov V. N. (2006) Introduction of a single application for the recognition of qualifications of Russian universities. Scientific Bulletin of the Moscow State Technical University GA. The series "International activities of universities". №. 102. Pp. 164-167. (in Russ). 